\title{
SINERGITAS PENGGIATAN EKONOMI KERAJINAN BATIK LAMPUNG, EKSPLORASI BUDAYA DAN EDUKASI KONSERVASI: ANDANAN BATIK TULIS, NEGERI SAKTI, PESAWARAN, LAMPUNG
}

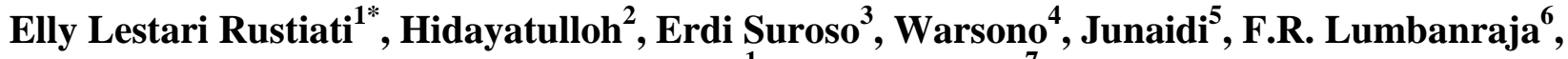 \\ Priyambodo ${ }^{1}$, S. Gitosaputro ${ }^{7}$ \\ ${ }^{1}$ Jurusan Biologi, Fakultas MIPA Universitas Lampung; \\ ${ }_{2}^{2}$ Pendidikan Matematika, STKIP Muhammadiyah Pringsewu; \\ ${ }^{3}$ Jurusan Teknologi Hasil Pertanian, Fakultas Pertanian, Universitas Lampung; \\ ${ }^{4}$ Jurusan Matematika, Fakultas MIPA Universitas Lampung, \\ ${ }^{5}$ Jurusan Fisika, Fakultas MIPA Universitas Lampung; \\ ${ }^{6}$ Jurusan Ilmu Komputer, Fakultas MIPA Universitas Lampung; \\ ${ }^{7}$ Jurusan Agribisnis, Fakultas Pertanian Universitas Lampung \\ Penulis Korespodensi : ely_jazdzyk@yahoo.com
}

\begin{abstract}
Abstrak
Batik Lampung merupakan salah budaya yang khas dengan motifnya dan menjadi salah satu kegiatan ekonomi yang kuat di Provinsi Lampung, termasuk kerajinan Andanan Batik Tulis, yang mencirikan keunikan budaya Lampung. Saat ini selain sebagai kegiatan kebutuhan ekonomi, kerajinan Andanan Batik Tulis sekaligus menjadi media edukasi budaya dan konservasi melalui pengkayaan motif berbasis budaya Lampung, konservasi dan penyediaan media belajar membatik. Penerapan edukasi budaya dan konservasi dilakukan melalui paket eduwisata yang disediakan bagi wisatawan baik lokal maupun asing. Program eduwisata ini mendapat tanggapan positif.
\end{abstract}

Kata Kunci: Andanan Batik Tulis, eduwisata, budaya, konservasi, Lampung

\section{Pendahuluan}

Pembangunan masyarakat desa dilaksanakan secara berkesinambungan, diperlukan edukasi, pelatihan, industri modal dan kebijakan yang berpihak pada kondisi masyarakat. Pengembangan ekonomi kreatif dipercaya dapat menjawab tantangan yang berkembang di bidang ekonomi (Gunaryo et al., 2008). Masyarakat tradisional juga semestinya menjadi pelaku yang dapat membuat pertumbuhan ekonomi negara Kolaborasi antar subsektor dan para pihak menjadi syarat mutlak pengembangan industri kreatif Indonesia (Haidawati dkk., 2015).

Ekonomi kreatif menjadi salah satu industri baru yang bertujuan untuk keberlangsungan industri dalam peningkatan pendapatan lokal. Keberhasilan program ekowisata tidak hanya pada jumlah kunjungan yang diterima tetapi juga tergantung pada kemampuan untuk memanfaatkan lingkungan dan potensi lokal dalam memenuhi kebutuhan wisatawan dan kemampuan menyerap aktifitas wisata (Butarbutar dan Soemarno, 2013). Kemampuan bekerja sama dengan masyarakat setempat secara mutualistik dengan kepercayaan masyarakat untuk bekerja sama menjadi kunci keberhasilan (Rustiati et al., 2015).

Pengembangan ekonomi kreatif berdasarkan budaya dapat dibangun dengan konsep rural tourism yang memperkenalkan produk unik kawasan tertentu yang ramah lingkungan. Rural tourism dikembangkan dengan proses pengenalan budaya masyarakat lokal kepada wisatawan agar dapat mengenal dan menikmati kehidupan masyarakat setempat. Dengan demikian tumbuh apresiasi pada nilai budaya dan kearifan lokal (Susyanti, 2013). Sebaliknya, dalam kegiatan pemberdayaan masyarakat, pembentukan dan pembinaan desa termasuk desa wisata dapat berdampak terhadap meningkatnya kesadaran dan kesejahteraan masyarakat melalui pengembangan ekonomi kreatif yang berkelanjutan (Rustiati dan Priyambodo, 2017). Wisata kreatif merupakan industri wisata modern untuk keberlanjutan indusri (Chooprayoon and Panyadee, 2013). Pengembangan ekonomi kreatif wisata desa di desa Braja Harjosari, Lampung Timur, merupakan salah satu contoh kegiatan unggulan yang mendapat tanggapan dan dukungan masyarakat dan pemerintah setempat, hingga dunia internasional 
(Rustiati dkk., 2016). Salah satu bentuk keberhasilannya adalah terjalinnya kerjasama dengan para pihak. Inovasi ilmu pengetahuan dan kreatifitas menjadi nilai positif dalam kegiatan pendampingan.
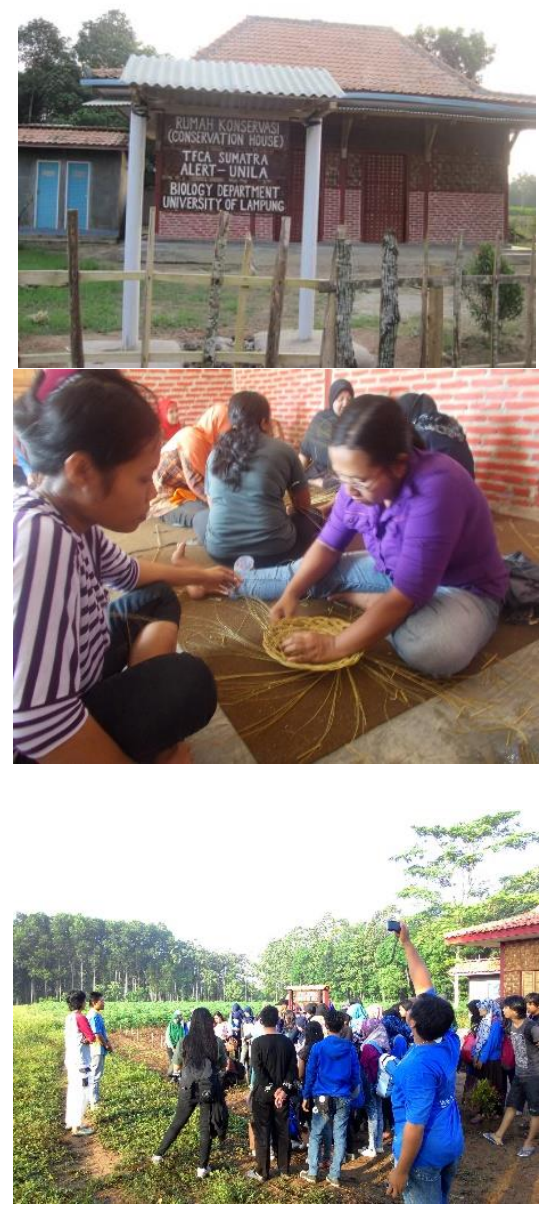

Gambar 1. Rumah Konservasi Margahayu, Lampung Timur dan aktifitas edukasi dengan masyarakat dan civitas akademika

Penyadartahuan dan peningkatan pengetahuan menjadi salah satu kunci dalam keberhasilan eduwisata seperti di Dusun Margahayu, labuhan Ratu VII, Lampung Timur ditunjukkan dengan penyerahan hak guna lahan seluas $1250 \mathrm{~m}^{2}$ untuk pembangunan Rumah Konservasi (Gambar 1). Rumah konservasi ini selanjutnya dimanfaatkan untuk kegiatan masyarakat desa, baik kebun tanaman badak (Rustiati dkk., dalam penerbitan), pelatihan, pengajian, pertemuan maupun edukasi masyarakat dari luar Desa Labuhan Ratu VII. Dengan bertumbuh kembangnya ekonomi kreatif atas kehendak dan kemampuan masyarakat sendiri, diharapkan dapat mendukung pelestarian budaya dan satwa seperti spesies kunci Sumatera, gajah sumatera dan badak sumatera. Pemahaman masyarakat terhadap satwa dilindungi menjadi semakin baik (Zimmermann et al., 2009).

Batik merupakan warisan budaya Indonesia dan dihargai sebagai salah satu warisan budaya dunia yang dihasilkan bangsa indonesia oleh UNESCO pada tanggal 28 september 2009. Pengakuan UNESCO diberikan terutama karena penilaian keragaman motif batik yang penuh makna filosofi mendalam. Disamping itu pemerintah dan masyarakat indonesia juga telah melakukan berbagai langkah nyata untuk melindungi dan melestarikan warisan budaya itu secara turun menurun.

Batik Lampung mulai berkembang pada tahun 1970-an, motif Lampung memiliki keunikan tersendiri. Motif batik Lampung sangat dipengaruhi kebudayaan India. Motif yang paling terkenal adalah motif perahu dan pohon hayat atau pohon kehidupan. Dua motif ini menjadi sangat khas bagi kebudayaan Lampung dan merupakan simbol Lampung di mata International. Saat ini di Provinsi Lampung khususnya di Kabupaten Pesawaran pembuatan batik tulis mulai berkembang dengan ragam motif-motif khas asli Lampung yang masih terbatas di Lampung. Salah satu usaha pembuatan batik tulis dilakukan oleh kelompokpengrajin "Andanan Batik Tulis", yang diambil dari istilah Kabupaten Pesawaran "Andan Jejama" yang berarti saling menjaga. Komitmen Andanan Batik Tulis adalah menyediakan batik tulis yang berkualitas dan bermotif Lampung yang akan mengangkat kearifan lokal Kabupaten Pesawaran khususnya.

Pemberdayaan masyarakat desa merupakan sebuah proses aktualisasi potensi desa sehingga masyarakat dapt hidup mandiri dengan potensi yang dimilikinya (Priyambodo dkk., 2018) dengan konsep pariwisata berbasis budaya (Priyambodo, dkk., 2015). Eduwisata batik tulis Andanan difokuskan pada perpaduan dan pendekatan multi target sehingga edukasi konservasi dapat dipahami bersamaan dengan budaya dan tradisi termasuk belajar teknik membatik.

\section{Metode Pelaksanaan}

Kegiatan ini dilaksanakan melalui diskusi melibatkan anggota kelompok pengrajin, pelatihan dan pendampingan untuk meingkatkan pengetahuan meliputi edukasi konservasi, wisata, potensi pengrajin, tata kelola, etika pelayanan, 
penguatan dan peningkatan kualitas produk, metode pemberdayaan dan pemasaran. Wisata kuliner diterapkan dengan penyajian dan makan bersama secara tradisional kepada tamu dan uji coba menerima tamu.

\section{Hasil Pendampingan}

Pendampingan ini menunjukkan bahwa Batik Tulis Andanan mempunyai potensi kerajinan tradisional yang dalam masa pendampingan telah menunjukkan bahwa penguatan produk batik dapat mendukung ekonomi keluarga dan memperkenalkan budaya batik Lampung yang unik dengan motif yang mewakili kekayaan budaya Lampung (Gambar 2).

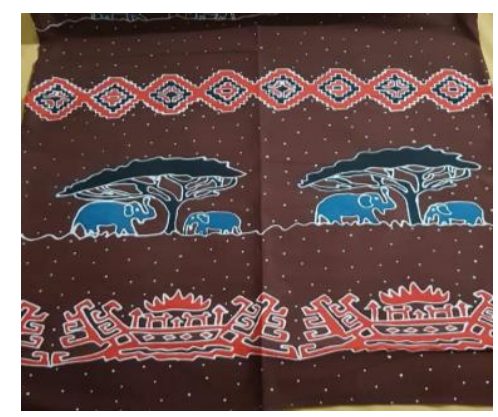

Gambar 2. Batik tulis Andanan dengan motif unik khas Lampung dan motif yang dipadu dengan edukasi konservasi

Selain menjalankan produksi batik, pengrajin Andanan Batik Tulis juga membuka peluang eduwisata dengan menerima kunjungan wisatawan untuk belajar pengetahuan tentang pembuatan batik sekaligus praktek membatik, baik untuk wisatawan lokal maupun asing. Pendampingan dilakukan dengan pemahaman dan pengetahuan konservasi seperti mengenali satwa endemik Sumatera (gajah sumatera (Elephas maximus sumatranus) dan badak sumatera (Dicerhorinus sumatranus), dan tumbuhan pakan alaminya yang tertuang dalam motif batik (Gambar 3).

Dampak dari kegiatan terlihat selain kemampuan kreasi desain batik khas Lampung juga ditunjukkan dalam penggambaran desain satwa dan tumbuhan yang benar, sebelumnya pengrajin belum bisa membedakan gajah afrika dan gajah sumatera.
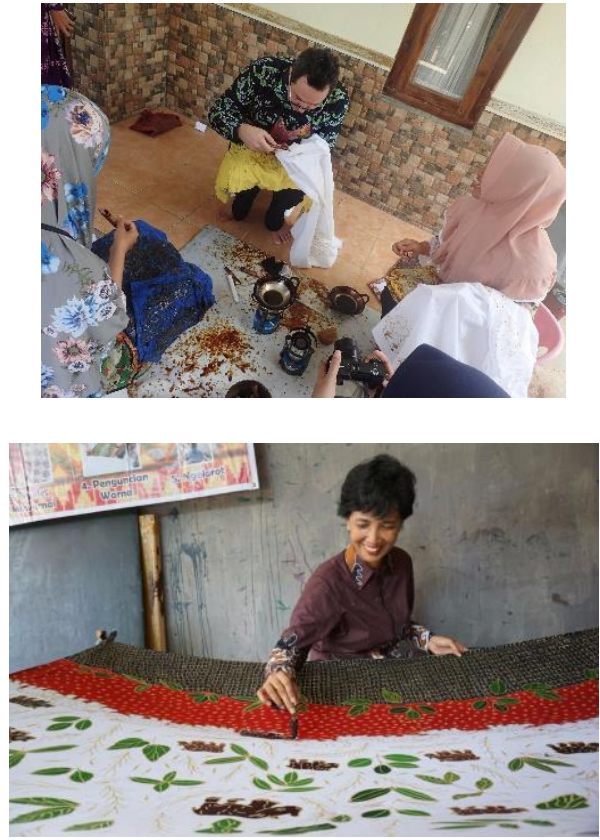

Gambar 3. Sinergitas budaya batik Lampung dengan edukasi konservasi gajah sumatera dan badak sumatera

Pengenalan kuliner tradisional "bacakan", yang merupakan acara makan bersama di atas daun sebagai simbul mempererat tali persaudaraan (Gambar 4). Selain memberikan sajian kuliner, paket ini juga memberikan pengetahuan budaya makan bersama masyarakat Lampung.

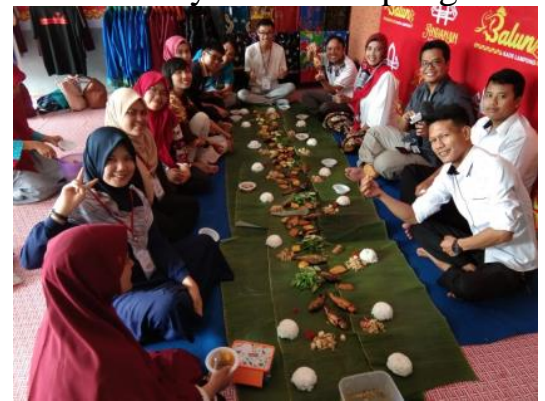

Gambar 4. Paket eduwisata bacakan di Andanan Batik Tulis, Pesawaran.

Uji coba paket belajar membatik menjadi salah satu sasaran edukasi budaya dengan motif batik khas Lampung dipadukan dengan kreasi dari wisatawan (Gambar 5). 


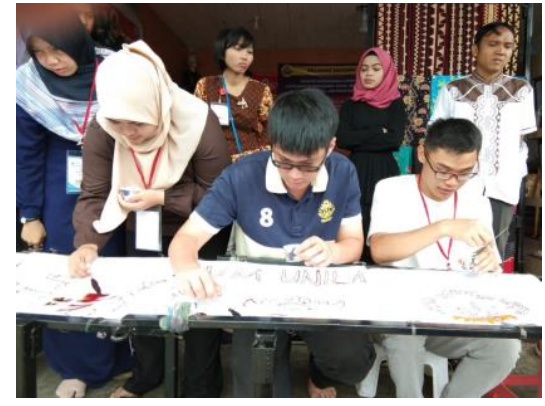

Gambar 5. Paket eduwisata belajar membatik untuk wisatawan di Andanan Batik Tulis, Pesawaran

Pengrajin yang sangat antusias, bangga akan budayanya dan berkomitmen, menjadikan sinergitas antara kerajinan batik khas Lampung dengan edukasi budaya dan konservasi, menghasilkan paket eduwisata dan peningkatan ekonomi. Peningkatan pendapatan masyarakat dan keterlibatan secara aktif menjadi kunci keberhasilan pertumbuhan ekonomi komunitas masyarakat (Pusiran dan Xiao, 2013).

\section{Ucapan Terima Kasih}

Terimakasih dan penghargaan yang setinggitingginya kepada masyarakat pengrajin Andanan Batik Tulis, Desa Negeri Sakti, Kabupaten Pesawaran, dan Kepala Desa Negeri Sakti atas kinerja dan kerjasamanya.

\section{Daftar Pustaka}

Butarbutar, R. dan Soemarno. 2013. Environmental effect of ecotourism in Indonesia. Journal of Indonesian tourism and development studies 1(3): 97-107.

Chaoprayon, P. and C. Panyadee. 2013. The local economic promotion through the creative tourism travelling route: The practical application for Chiangrai Procince, Thailand. GSTF Journal on Business Review (GBR) 3 (1): 123-128.

Gunaryo, Ernawati, D. Sudarman, H.B. Wibowo dan P. Ambarita. 2008. Studi industri kreatif Indonesia. Departemen Perdagangan RI.

Haidawati, E.L. Rustiati, M. Kanedi, Priyambodo. 2015. Agrowisata kebun jambu Kristal sebagai potensi ekonomialternatif desa penyangga Taman
Nasional Way Kambas, Lampung Timur. Prosiding Seminar Nasional Pengabdian kepada Masyarakat: Pemberdayaan masyarakat melaluipengembangan ekonomi kreatif dalam meningkatkan pembangunan daerah. LPPM Universitas Lampung: 387-395.

Pusiran, A.K. and H. Xia. 2013. Challenges and community development: A case sudy of homestay in Malaysia. Asian Social Science 9(5):17

Priyambodo dan E.L. Rustiati. 2016. Rumah konservasi Biologi Unila, Margahayu, Lampung Timur: Apresiasi masyarakat desa penyangga Taman Nasional Way Kambas dalam upaya konservasi. Prosiding Seminar Nasional Hasil-hasil Pengabdian kepada Masyarakat Universitas Lampung 2016, LPPM Universitas Lampung: 353-357.

Priyambodo, N. Nurcahyani, E.S. Ariyanti, Haidawati. 2015. Potensi kesenian Bali sebagai asset pengembangan ekonomi kreatif Wisata desa penyangga Taman Nasional Way Kambas di Kabupaten Lampung Timur. Prosiding Seminar Nasional Pengabdian kepada Masyarakat: Pemberdayaan masyarakat melaluipengembangan ekonomi kreatif dalam meningkatkan pembangunan daerah. LPPM Universitas Lampung: 396-403.

Rustiati, E.L. dan Priyambodo. 2017. Laporan Kegiatan Tridharma Perguruan Tinggi (tidak diterbitkan).

Rustiati, E.L., N. Nurcahyani, J. Master. 2016. IbM Wisata desa penyangga Taman Nasional Way Kambas, Lampung. Laporan akhir.

Rustiati, E.L., J. Master, D. Wibowo. A.E. Cesario. 2015. Penguatan ekonomi alternatif masyarakat desa penyanggaPelatihan pengemasa prodk makanan tradisional di Desa Braja Indah, Lampung Timur. Prosiding Seminar Nasional Pengabdian kepada Masyarakat: Pemberdayaan masyarakat melaluipengembangan ekonomi kreatif dalam meningkatkan pembangunan daerah. LPPM Universitas Lampung: 377-386.

Zimmermann, A., T.E. Davies, N. Hazarika, S. Wilson, J. Chakrabarty, B. Hazarika and D. Das. 2009. Community based human-elephant conflict management in Assam. Gajah 30: 34-40. 